\title{
A espiritualidade nos sermões de Paul Tillich
}

\author{
Alex da Silva Mendes*
}

\begin{abstract}
RESUMO
O objetivo desse artigo, é enfatizar a vida devocional de um dos mais importantes teólogos de todos os tempos. Embora Paul Tillich fosse essencialmente pensador e erudito, sua vida acadêmica jamais o afastou do púlpito. A relação de Tillich com a vida pastoral, está evidenciada em seus sermões. A vida eclesial sempre fez parte dele. A espiritualidade ocupou espaço relevante em seu dia a dia. Tillich abordava questões teológicas profundas com uma linguagem simples, como um meio prático de aproximar seus ouvintes da mensagem do evangelho. A trajetória de Tillich como capelão, pastor e pregador, o levou a refletir sobre uma profunda espiritualidade, deixando sobressair o ser humano por traz do teólogo.
\end{abstract} Palavras-chave: Paul Tillich; espiritualidade; teologia; sermões.

\begin{abstract}
The purpose of this article is to emphasize the devotional life of one of the most important theologians of all time. Although Paul Tillich was essentially a thinker and scholar, his academic life never took him away from the pulpit. Tillich's relationship with pastoral life is evident in his sermons. Ecclesial life has always been part of it. Spirituality occupied a relevant place in their daily lives. Tillich addressed deep theological issues in simple language, as a practical means of bringing his listeners closer to the gospel message. Tillich's trajectory as a chaplain, pastor and preacher took him and reflect on a profound spirituality, letting the human being stand out behind the theologian.
\end{abstract}

Keywords: Paul Tillich; spirituality; theology; sermons.

Mestrando em Teologia pela Pontifícia Universidade de São Paulo, membro do grupo Lerte e da Sociedade Paul Tillich do Brasil. 


\section{Introdução}

Paul Tillich é um dos principais pensadores do século XX, era contemporâneo de Karl Barth. Segundo (Hordern, 2003, p. 210)1, "Tillich é típico da erudição alemã no que ela tem de melhor. Não há nenhum teólogo americano que disponha de tanta riqueza de pesquisa histórica como se vê em Tillich". É considerado por muitos estudiosos, como teólogo dos teólogos. Grande parte de suas obras, já foram traduzidas para a Língua Portuguesa. Infelizmente, a ausência de conhecimento sobre as obras de Tillich, têm levado muitos, a tecerem críticas descabidas sobre ele. É importante enfatizar, que além de teólogo, filósofo e professor universitário, ele também era pastor luterano. Como pastor, elaborou vários sermões, que são preciosidades literárias. A relevância de seus sermões, estão registrados em seus livros. A espiritualidade está presente em toda vida e literatura tillichiana. Alguns alunos de Tillich, deixaram registros surpreendentes a respeito de suas aulas e sermões.

Falando sobre a relevância dos sermões de Tillich, (Parrella, 2004, págs. 64-65) nos fala assim: "Ele relaciona o mistério da vida interior com a vida na sociedade e na comunidade. A partir do século doze acentuou-se infelizmente a separação entre spiritualitas e corporalitas, entre a vida no espírito e a vida material no mundo. Tillich não acreditava nessa separação. Essas vidas eram inseparáveis: da mesma forma o corpo a alma eram uma só pessoa. No sermão, "O bem que eu quero, não faço", escreve; "Paulo, e com ele toda a Bíblia, nunca responsabiliza o corpo pela nossa separação de Deus, do mundo e de nosso eu". No sermão, "O novo ser", escreve: "A cura - mental e física - cria a reunião do eu consigo mesmo... a verdadeira cura não se dá quando o corpo ou a mente se reúne com o todo, mas quando o eu total, o ser inteiro e a personalidade toda se unem com o eu". Mais importante do que isso, ele nunca separa a jornada espiritual da vida da pessoa na sociedade. Em "O novo ser", acrescenta: “ Nada é mais apaixonadamente exigido do que a cura social, do que o poder do Novo Ser na história e nas relações humanas. "E em "Dois servos de Javé", Tillich nos lembra

HORDERN, William E. Teologia contemporânea. São Paulo: Hagnos, 2003.

2 PARRELLA, Frederick J. Vida e Espiritualidade no pensamento de Paul Tillich.

Revista Eletrônica Correlatio n. 6 - novembro de 2004. 
de que os servos profetas, como o servo sofredor, " existem invisíveis em todos os países... sabemos que existem e que seu sofrimento não é em vão. São os instrumentos ocultos de Deus na história".

Tillich é sem dúvida, um teólogo pastor que sempre prezou pela espiritualidade em sua vida pessoal e eclesial. Ao lado do acadêmico, sempre esteve o pastor e homem de família. A medida que nos aproximamos dos escritos e da vida de Paul Tillich, nos apaixonamos pela espiritualidade desse importante servo de Deus.

\section{A Igreja, um espaço de fé e reflexão para Tillich}

Paul Tillich nasceu na Prússia em 1886. Seu pai, que era ministro Luterano, estudou teologia e filosofia nas Universidades de Berlim, Tübingen e Halle, entre 1904 e 1912. Tillich recebeu seu PhD em 1911 e foi ordenado ministro Luterano em 1912. Ele disse que igreja sempre foi sua casa, que sempre sentiu muito medo, de perder àquele espaço político e sagrado. Paul Tillich, (Tillich, 2016, págs. 69-70)3 explica isso da seguinte forma:

Meu intenso amor pelo templo com seu misticismo, o grande amor pela liturgia, pelo canto e pelos sermões nos festivais da Igreja os quais, durante dias até mesmo semanas, determinavam a vida da cidade, meu amor pelos mistérios da doutrina da Igreja e seus efeitos sobre minha vida espiritual de criança, a experiência emocionante da santidade, da culpa e do perdão, a linguagem da Bíblia, particularmente os seus enérgicos provérbios, tudo isso, junto, foi eficaz em mim e me criou um fundamento, que conduziu-me a decisão de me tornar um teólogo e de manter-me como tal, apesar de todas as tensões. De igual modo, os exames canônicos, minha ordenação, a atividade como pastor por certo número de anos e meu interesse nos sermões e na liturgia mesmo muito tempo após minha transferência definitiva para a universidade, são consequências de meu sentimento de relação ativa com a Igreja.

O ambiente eclesial, foi um importante espaço de reflexão para Tillich. Foi na igreja, onde ele desenvolveu importantes pensamentos teológicos e filosóficos. O contato com o contexto eclesiológico, levou Tillich a desempenhar seu ministério pastoral e a elaborar excelentes sermões. Esse ambiente de espiritualidade é imprescindível para o

3 TILLICH, Paul Johannes. No Limite. Organizador - São Paulo - Fonte Editorial, 2016. 
conduzi-lo ao espaço universitário. Ele mesmo nos informa, que a sua transferência definitiva para os estudos acadêmicos, se dão a partir do seu sentimento de relação ativo com a Igreja. Tillich continua falando sobre isso, em sua Teologia Sistemática: (Tillich, 2005, p. 63$)^{4}$ o teólogo, para dialogar com as culturas, não precisa abandonar a Igreja.

Pelo contrário, Tillich diz que a Igreja é o "lar" do teólogo. É a partir da Igreja, nela enraizado, sem se levar pelo ostracismo, que as fontes e as normas da teologia têm existência real. Só neste lugar a experiência pode converter-se em meio da teologia. O teólogo sem senso de pertença perde o lugar de trabalho. A Igreja "é seu lugar mesmo que ele trabalhe e proteste contra ela. O protesto é uma forma de comunhão [...] para ser uma norma genuína, não deve ser uma opinião privada do teólogo, mas a expressão de um encontro da Igreja com a mensagem cristã, conclui Tillich. Ele diz que na Igreja, se revela o conceito de fronteira. Sua experiência social, aquilo que ele chama de Intelligentsia, e a experiência com o proletariado, apologética e o Logos, se dão a partir de uma reflexão teológica. Percebe-se que para Tillich, teologia e Igreja devem andar de mãos dadas. Uma complementa a outra. Apesar de algumas experiências ruins, não podemos generalizar. Muitos teólogos e teólogas, querem impor às Igrejas, um academicismo e uma linguagem difícil para a realidade daquela comunidade de fé. Por isso, muitas Igrejas passaram a não terem muita expectativa contributiva da teologia. Tillich chama à nossa atenção para o pensar teológico, também no espaço de fé. De acordo com (Zuben, 2019, p. 1) $)^{5}$ : "na afirmação de Tillich, é interessante perceber que teologia "é função da igreja cristã", ou seja, para ele, paira sobre a igreja a responsabilidade e o dever de fazer teologia. Isto se dá pelo fato da igreja necessitar da reflexão e da afirmação sobre a "verdade da mensagem cristã" diante de tantos desafios e sonhos cultivados, bem como da interpretação e atualização da mensagem cristã para cada geração. Diante desta realidade, é interessante perceber também que, para Tilich, a teologia "deve servir às necessidades da igreja". Este "servir" não é no sentido

4 TILLICH, Paul Johannes. Teologia Sistemática. 5.ed. São Leopoldo: Ed. Sinodal, 2005. p.63.

5 ZUBEN, Reginaldo von. Teologia e Igreja. Fatipi - Faculdade de Teologia de São Paulo - 8 de novembro de 2019. 
de "quem sabe tudo em relação ao quem não sabe nada". Longe disto. Ao mesmo tempo, não é o "servir" passivo, submisso e que aceita tudo, sem julgar, criticar ou indicar os erros que a igreja comete. Julgamos que o "servir" se dá no diálogo, na caminhada, nos mesmos interesses, visando a glória de Deus e o fortalecimento e crescimento do povo de Deus". Tillich entende é claro, que a igreja é um importante espaço de fé e espiritualidade. Para Tillich, a igreja deve ter a função de responder sobre as implicações da existência humana e seu significado. Ela deve apresentar de forma adequada a mensagem do evangelho, e através disso, enfatizar às pessoas de fora os símbolos que expressa esse lugar da igreja na cultura contemporânea. Ele insiste que a mensagem cristã é a mensagem de salvação.

Para Tillich, a mensagem cristã significa cura; cura das angústias e o desespero de milhões em desespero em relação a existência. A igreja não tomar o caminho da promessa de cura, antes deve entender que sua pregação é levar uma mensagem que alcance as pessoas em seu próprio tempo. O cristianismo não pode ser entendido como um sistema de doutrinas ou algo assim. A igreja para ele, deve ter uma nova realidade curadora. Ainda falando sobre o papel da igreja, (Tillich, 2020, p. 60$)^{6}$ diz o seguinte:

Ainda uma última questão permanece, a como a Igreja deveria tratar com o espírito da nossa sociedade que é responsável por muito do que deve ser curado pela mensagem cristã. Terá a Igreja o poder e a tarefa de confrontar e trane formar o espírito da sociedade industrial? Certamente, ela não pode tentar substituir a presente realidade social por uma outra, em termos de progresso para a realização do Reino de Deus. Ela não pode esboçar estruturas sociais perfeitas ou sugerir reformas concretas. As mudanças culturais ocorrem por meio de dinâmicas internas à própria cultura. A Igreja participa nelas, algumas vezes exercendo o papel principal. Mas, nesse caso, ela é uma força cultural ao lado de outras e não a representante de uma nova força na história.

Para Tillich, o papel profético da igreja é revelar as estruturas demoníacas na sociedade em seus aspectos de estruturas, mesmo dentro da própria igreja. Dessa forma a igreja poderá ouvir as vozes profé-

${ }^{6}$ TILLICH, Paul Johannes. Textos Selecionados. São Paulo. Fonte Editorial, 2020. 
ticas fora dela. É preciso julgar ambas, lembrando que à igreja está inserida na cultura e faz parte dela. Tillich enfatiza, que a maior das vozes, vem de fora da igreja. Por isso, a igreja deve torna-se visível. Outro ponto importante, é o fato de que a igreja deveria reconhecer as vozes e os espíritos nesse contexto cultural e manter-se em guarda contra as distorções demoníacas no âmbito nos quais o confronto está estabelecido. Tillich estabeleci uma ponte entre a igreja e a cultural, não se contrapondo nem a um, nem a outro. Ele está estabelecendo um diálogo entre esses dois pontos importantes. Para ele, julgar significa enxergar ambos os lados. A igreja deve analisar não só a cultura, mas a sua própria forma de vida entrelaçadas entre ambas.

\section{Paul Tillich, capelão cristão durante a I Guerra Mundial}

A primeira guerra mundial (1914-1918), foi uma das grandes tragédias, que mais afetaram a humanidade, não apenas pelos 22 milhões de mortos, mas porque o mundo perdeu gerações de vidas; entre elas estavam: médicos, filósofos, construtores, músicos, escritores, poetas, cientistas, artistas, soldados, camponeses etc.

De acordo com (Campos e Miranda, 2005, p. 442)7: "Os soldados que foram cantando para a guerra, contavam com um conflito curto". No início dos combates, políticos, líderes militares e a imprensa patriótica prometiam: "Os soldados já estarão em casa para as festas de fim de ano". Ninguém imaginava quatro anos de derramamento de sangue. Sim, a primeira guerra mundial, foi um verdadeiro banho de sangue. Milhões de pessoas morreram envenenadas, destruição de cidades e populações civis, idosos, mulheres, crianças e animais. Segundo (Botelho, 2021, p. 1) $)^{8}$ :

A Europa nunca se recuperou do trauma da 1 Guerra Mundial. Entre os ex-combatentes, muitos enlouqueceram. Alguns se tornaram poetas e pacifistas. E outros, brutalizados pelos horrores do front, foram engrossar as fileiras de movimentos fascistas que ganharam corpo no pós-guerra. Entre os rancorosos veteranos que retornaram derrotados à Alemanha,

7 CAMPOS, Flavio de; MIRANDA, Renan Garcia. A escrita da história: volume único. $1^{\mathrm{a}}$. Ed. São Paulo, 2005.

8 BOTELHO, José Francisco. A história da Primeira Guerra Mundial. Super interessante. Disponível em: https://super.abril.com.br/especiais/a-historia-da-primeira-guerra-mundial/. 
havia um jovem soldado raso chamado Adolf Hitler. "O conflito não resolveu nada, apenas agravou as rivalidades que já existiam em 1914", escreve Hobsbawn.

A primeira guerra mundial causou imensa dor e sofrimento em todos os aspectos da vida humana. A atividade de assistência religiosa, era uma forma de trazer conforto físico e espiritual, mas também uma difícil maneira de se deparar com uma realidade cruel, com a desintegração do ser humano. A Alemanha estava presente na primeira guerra mundial, que uma guerra de blocos de nações imperialistas e industriais. Como era de se esperar na época da Revolução Industrial, a Europa serviria como um grande laboratório de fabricação de armas novas para a época. Como resultado disso, as mortes durante o conflito foram mais contundentes. Armas como a granada de mão, os tanques de guerras, os lança-chamas surgiram tudo durante o conflito, e consequentemente a capacidade de devastação era devastadora.

Em 1918, após ser derrotada no conflito, a Alemanha foi humilhada pelo Tratado de Versalhes. O foco era inviabilizar economicamente a Alemanha que tinha que se render sem ter um soldado sequer em seu território, além de ter que reduzir sua frota mercante e seus investimentos na área militar, tendo que limitar a sua tropa em apenas 100 mil homens. No período pós-guerra, com a crise de 1929 em Nova York, o povo alemão entrou em desespero, pois antes de 1918 o marco ele era valorizado, com a crise ele se desvalorizar tanto que chegou ao ponto de que um dólar americano passou a valer quatro trilhões de marcos alemães. Isso gerou além da fome, uma dor aguda, que é muito bem trabalhada pelos partidos que queriam um cenário favorável para a criação de um novo conflito. Paul Tillich, serviu como capelão no Exército alemão na primeira guerra mundial. Ele teve várias experiências terríveis, que pôde acompanhar os horrores pelos quais a Europa continuaria a passar ao longo das décadas seguintes. A partir de uma análise de sua trajetória pessoal, constata-se que os fatos ocorridos na vida de Paul Tillich influenciaram grandemente sua teologia. (Hordern, 2003, p. 209) $)^{9}$ diz:

9 HORDERN, William E. Teologia contemporânea. São Paulo: Hagnos, 2003. 
"Ele exerceu capelania por quatro anos durante a Primeira Guerra Mundial, os quais lhe causaram uma impressão vívida a respeito dos problemas sociais. Voltou do cenário da guerra para empenhar-se em atividades relacionadas com o funcionamento do Movimento Socialista Religioso na Alemanha, atividade que tornou inviável sua presença no país sob Hitler".

Sabemos que Paul Tillich nasceu em lar cristão luterano, na cidade alemã de Starzddel, perto de Berlim, e 1886. Em 1910, graduou-se no doutorado em Filosofia, em Breslau, e em 191 licenciou-se em Teologia, em Halle. O próprio Tillich nos informa, que desde muito cedo, ele teve contato com o luteranismo desde o nascimento. Do luteranismo, ele obteve uma educação e uma profunda reflexão e experiência religiosa. Como se sabe Tillich, dialogou com movimentos políticos, sociais, filosóficos, científicos e artísticos de sua época. Sempre esteve em busca de uma dimensão religiosa suprema presente nas culturas do seu tempo.

Como sabemos, Tillich serviu como capelão na primeira guerra mundial no exército da Alemanha. Ele foi muito afetado psicologicamente pela visão das mortes e da destruição em massa causadas por causa da guerra. Ele sofreu dois colapsos nervosos e sua fé em um cristianismo romantizado alemão de sua época ficou abalado. O próprio (Tillich, 2009, p. 10) ${ }^{10}$, conta como foi esse sofrimento em sua vida:

"A transformação ocorreu durante a batalha de Champagne, em 1915. Houve um ataque noturno. Durante toda a noite, não fiz outra coisa senão andar entre feridos e moribundos. Muitos deles eram meus amigos íntimos. Durante toda aquela longa e terrível noite, caminhei entre filas de gente que morria. Naquela noite, grande parte da minha filosofia clássica ruiu em pedaços. A convicção de que o homem fosse capaz de apossar-se da essência do seu ser, a doutrina da identidade entre essência e existência. Lembro-me que sentava entre as árvores das florestas francesas e lia "Assim Falou Zaratustra", de Nietzsche, como faziam muitos outros soldados alemães, em contínuo estado de exaltação. Tratava-se da liberação definitiva da heteronomia. O niilismo europeu desfraldava o dito profético de Nietzsche, "Deus está morto? Pois bem, o conceito tradicional de Deus estava mesmo morto".

Para Tillich, o mundo e a esperança na cultura alemã estavam em pleno colapso. Ele diz que os quatro anos que passou na

10 TILLICH, Paul Johannes. Teologia da Cultura. São Paulo. Fonte Editorial, 2009. 
guerra, lhes trouxeram danos irreversíveis. Tillich nos diz, que foi em Verdun, que ele abandonou o liberalismo teológico alemão. Ele acrescenta com muita tristeza, que naquela noite, em meio os barulhos de canhões, que durante horas, ofereceu conforto aos doentes e moribundos, que chegavam no acampamento, pela manhã, cansado, que dormiu entre cadáveres. Ele diz, que ali, naquele caos, morreu seu idealismo teológico. Tillich relata o fracasso da fé e a crise de sua de convicção. Ele teve uma experiência bem particular, como capelão na I Guerra Mundial. Ele reflete sobre a condição humana enquanto demonstração da situação espiritual do momento que se abria para o mundo. Seu destino pessoal, coincidia com o destino de milhões de pessoas da Europa inteira. Com a derrota da Alemanha e o fim da monarquia Tillich vê algo novo emergindo do desastre.

A I Guerra Mundial trouxe mudança de uma construção de algo novo. Tillich diz que o julgamento da I Guerra Mundial, o levou à compreensão de não se pode divinizar nenhuma construção política.

Ele entende que esse julgamento, tem um aspecto positivo chamado de kairós, que para ele é um momento de graça onde a possibilidade humana se toma plena de força divina. Segundo Tillich, esse kairós se diferencia das propostas daquelas postas pelos socialismos que se colocaram em favor da guerra, para ele, esse kairós aponta para a possibilidade de algo novo. Essa esperança é maior que uma simples ilusão humana, pois é uma esperança que tem o próprio Deus como fundamento e essa graça gera o kairós. Paul Tillich é herdeiro do pensamento alemão. Ele é devedor do idealismo alemão, em especial de Hegel e Schelling. De acordo com (Mundo Educação, 2021, p.1):11 "O idealismo não é uma simples teoria, mas um conjunto de teorias filosóficas metafísicas complexas que entendem a realidade como uma complexidade existente em, pelo menos, dois planos: um plano material (da realidade material, sensorial e perceptível) e um plano ideal, de uma existência ideal, onde se estabelecem apenas conceitos, significados e formas perfeitamente estabelecidas. Podemos remontar o idealismo

11 EDUCAÇÃO, Mundo. Idealismo. Disponível em: https://mundoeducacao.uol.com. br/filosofia/idealismo.htm\#: :text=Os\%20fil\%C3\%B3sofos\%20do $\% 20$ idealismo $\% 20$ alem $\%$ C3\%A3o,Friedrich\%20Wilhelm\%20Joseph\%20Schelling. 
a Platão, e temos um desenvolvimento maior da corrente com os idealistas alemães do século XVIII. O idealismo parte do princípio de que há a existência metafísica de uma realidade complexa e ideal. O que é ideal é aquilo que existe enquanto ideia, enquanto conceito, como algo descolado da matéria. O idealismo é justamente a afirmação desses ideais como ponto central do conhecimento".

Para Tillch, a cultura é a produção humana em toda sua riqueza e diversidade. Para ele a cultural faz parte de uma produção intelectual. As manifestações culturais fazem parte da manifestação religiosa. A religião faz parte de uma manifestação especial, que se apresentam enquanto cultura. Por isso, o diálogo com artistas e escritores é imprescindível no mundo democrático contemporâneo. Dessa forma, Tillich é um teólogo da cultura e um filósofo da religião. Para Tillich é preciso abandonar aquele Deus estabelecido pela teologia do século dezenove e perfazer um cristianismo que responda aos problemas da contemporaneidade. A I Guerra Mundial faze-nos repensar esse cristianismo que levou a se aproximar do Partido Social Democrata alemão. Tillich desenvolve suas reflexões em direção de uma filosofia da história, alinhada com a sociologia e filosofia.

\section{Paul Tillich e a pregação do evangelho}

Durante toda trajetória acadêmica e pastoral de Tillich, ele esteve comprometido com palestras, aulas e pregações. Os sermões de Tillich estão registrados em suas obras literárias. Antes de falar sobre os sermões de Tillich, é importante enfatizar a preocupação com a comunicação da mensagem cristã. Em sua obra, Textos Selecionados, (Tillich, 2020, p. 15) 12 $^{2}$ os diz: “O que é a mensagem cristã? Mas, antes: Como deve ser focada a mensagem (que é pressuposta) para as pessoas do nosso tempo? Em outras palavras, nós estamos preocupados aqui com a seguinte questão: Como pode o Evangelho ser comunicado? Estamos perguntando: Como fazer para tornar a mensagem ouvida e vista e, ou aceita?".

Como exímio expositor da mensagem cristã, Tillich vai falar que comunicar o evangelho significa colocá-lo diante das pessoas até que

12 TILLICH, Paul Johannes. Textos Selecionados. São Paulo. Fonte Editorial, 2020. 
elas estejam receptivas para ouvi a mensagem, contra ou a favor. Para ele, a mensagem evangélica implica numa questão de decisão. Nesse sentido, a comunicação da mensagem do evangelho, deve passar por uma genuína decisão. Para Tillich, o evangelho deve aceito ou não! A decisão deve estar baseada numa plena compreensão. Tillich deixa claro, que sofremos quando as pessoas rejeitam a mensagem do evangelho. Não podemos estar alheios ou despreocupados do alcance da mensagem do evangelho. Claro que queremos que todas as pessoas respondam positivamente à mensagem do evangelho. Como pregadores da mensagem cristã, temos que entender os outros e participar da existência deles. Como veremos a seguir, os sermões de Tillich é um convite à reflexão. Em Mateus 14.23, ele fala sobre a importância da solidão. Na coletânea The New Being, ele traz um sermão intitulado “O Novo Ser” baseado em Gálatas 6.15 ("nem a circuncisão é coisa alguma, nem a incircuncisão, mas o ser nova criatura"). O relato da ressurreição, baseado em 1 Coríntios 15. Ainda temos outro sermão, baseado em Romanos 7, onde ele fala sobre a fraqueza humana. Tillich elaborou vários sermões, como podemos ver, ele prezada pela relevância da mensagem cristã, com um sentido repleto de profundidade e espiritualidade. Temos, ao todo, sessenta e três sermões publicados nos três livros. A grande maioria baseia-se no Novo Testamento, especialmente os evangelhos. Há onze sermões baseados no evangelho de João, dez em Mateus, cinco em Lucas e quatro no evangelho de Marcos.

Dos textos paulinos, Tillich privilegia especialmente, Romanos (oito sermões) e I Coríntios (sete vezes). O Antigo Testamento serve como base vinte e duas vezes, com especial predileção pelos profetas (seis sermões baseados em Isaías, quatro em Jeremias e um em Ezequiel) e os Salmos (oito sermões baseados nos Salmos).

Os sermões de Tillich, nos conduzem a uma verdadeira espiritualidade. Baseado em Mateus 14.23, ele fala sobre a importância da solidão. Tanto Mateus, quanto João relatam esse episódio. Em Mateus temos uma belíssima pintura, de Jesus se retirando para orar sozinho no monte, enquanto seus discípulos enfrentam uma tempestade no lago. $\mathrm{O}$ evangelho de João 6.15, relata que Jesus estava ansioso para dispensar a multidão: ela tinha sido alimentada com pão e queria torna-la Rei! Os homens seguem qualquer um que lhes prometa coisas matérias, porém 
Jesus não queria discípulos influenciados por isso. Jesus não seria Rei para um grupo de pessoas que estava apenas interessado em encher o estômago. Ele afastou-se da multidão e enviou os discípulos para o outro lado do mar, sabendo que havia uma tempestade a caminho. Tillich sabe da importância dessa narrativa, mais ele aprofunda mais ainda seu sermão, ele se atém a um detalhe imprescindível. Como diz (Calvani, 2004, p. 142) "13 "no sermão, Tillich observa que a palavra "isolamento" tem uma característica negativa - expressa a dor de estar sozinho e é fonte de melancolia, porque ninguém escapa do isolamento da própria culpa e da morte que é só nossa e de mais ninguém. A palavra "solidão", por sua vez, tem características positivas, pois expressa a glória de estar sozinho. Isso significa que, de certo modo, depende de nós, transformar a destrutividade do isolamento em solidão criativa. Falando de si mesmo no sermão, ele diz que frequentemente se retira para estar só com sua solidão". Tillich nos conta como vivia os seus momentos de solidão. Nesses momentos nos encontramos em uma vivida batalha, uma batalha entre a criatividade e a destrutividade, entre Deus e os demônios. Por isso, diz Tillich, a solidão e o isolamento não são nada fáceis. Mas, é nesses momentos de profunda reflexão, que podemos tirar proveito da solidão. Ele enfatiza, que o próprio Deus, as vezes nos afasta das multidões, para que possamos superar os obstáculos e as crises internas. Deus nos põe em isolamento, para que possamos crescer.

Um outro importante sermão de Tillich, tem como base "O Novo Ser" baseado em Gálatas 6.15 ("nem a circuncisão é coisa alguma, nem a incircuncisão, mas o ser nova criatura"). É importante enfatizar, que que nessa narrativa, o apóstolo Paulo diz respeito a alguns legalistas. De acordo com (Wiersbe, 2009, p. 756) ${ }^{14}$ ele remove esses legalistas os criadores de problemas com um movimento da pena. Paulo escreve: "Pois nem a circuncisão é coisa alguma $[\ldots]$ e $[\ldots]$ todos quantos andarem de conformidade com esta regra [...] porque eu trago no corpo as marcas (estigmas]

13 CALVANI, Carlos Eduardo B. Espiritualidade e Pregação. Revista Eletrônica Correlatio n. 6 - novembro de 2004.

14 WIERSBE, Warren W. Comentário Bíblico Novo Testamento - A Bíblia explicada de maneira clara e concisa. $1^{\mathrm{a}}$ edição, Rio de Janeiro: 2009. 
de Jesus". Isso quer dizer que ele tem cicatrizes no corpo que provam que sofreu reprovação por causa da cruz de Cristo, e não que tenha cinco feridas no corpo semelhantes às de Jesus Cristo. $\mathrm{Na}$ época de Paulo, os homens estigmatizavam os soldados, os escravos e as pessoas que se dedicavam a um deus. Paulo era soldado, escravo e seguidor devo- atado de Cristo. Ele encerra com uma bênção maravilhosa: "A graça de nosso Senhor Jesus Cristo seja, irmãos, com o vosso espírito" (v. 18).

Ao fazer referência a esse texto, Tillich saí da superfície e aprofunda o significado literário dessa narrativa paulina. Falando sobre a circuncisão ou a incircuncisão, ele fala sobre o ser nova criatura. Aprofundando a argumentação paulina, Tillich nos diz que não importa ser judeu ou gentio, para ele o mais importante é a união com Aquele em quem a Nova Realidade está presente. Nesse sentido, para ele, o cristianismo enquanto religião particular, tem pouca relevância diante da circuncisão ou inciruncisão, não é menos ou mais importante. Para falar sobre a importância do novo Ser ou Nova Realidade, Tillich emprega uma linguagem homilética, para nos dizer, que nenhuma religião particular é preponderante. De acordo com (Calvani, 2004, p. 150) 15, "A Nova Criação começou; o Novo Ser apareceu; e nós somos chamados a participar dessa realidade". Aqui ele remete novamente à imagem do Cristo, dizendo que "O Novo Ser se manifesta em Cristo porque Nele as forças da alienação nunca foram capazes de superar a unidade entre Ele e Deus, entre Ele e a humanidade, entre Ele e Ele mesmo... Ele representa e media o poder do Novo Ser porque Ele representa e media o poder de uma união inseperável". O uso da linguagem direta é retomado na conclusão, numa espécie de "apelo" aos ouvintes: "A reconciliação acontece agora... Aceite-a, deixe a tomar conta de você".

Um outro sermão não menos importante de Tillich, está baseado em 1 Coríntios 15, no relato da ressurreição, ele fala sobre a importância da linguagem simbólica. Na narrativa bíblica, o

15 CALVANI, Carlos Eduardo B. Espiritualidade e Pregação. Revista Eletrônica Correlatio n. 6 - novembro de 2004. 
apóstolo Paulo inicia sua argumentação sobre a ressurreição do corpo humano com a de Cristo. Tillich não está preocupado com a literalidade da narrativa textual. Saber se a ressurreição é um fato histórico ou não, não é um fator preponderante. Para Tillich essa narrativa poética da sepultura vazia, é um aspecto simbólico da Bíblia. Tillich recomenda esse método de pregação para todos os sermões. Por isso, diante do infortúnio do término da vida, a questão sobre o literalismo ou não, nós pregadores, temos o poder da palavra. Ele sempre está preocupado com aquelas pessoas que questionam a validade dos símbolos cristãos. Tillich diz está sensível para não se tornar uma pedra de tropeço a fé dos seus ouvintes. Para ele, a linguagem dos símbolos não inclui há interpretação para o modo literal. Ele enfatiza que para a mensagem ser comunicativa e eficaz, a linguagem homilética deve ser própria ao ambiente. Para Tillich, o problema central da linguagem cristã: a identificação do poder salvífico comunicado pelos símbolos cristãos com as doutrinas formuladas a partir dos mesmos. Para ele, a verdade cristã não é a verdade doutrinária, mas a verdade que é o próprio Cristo enquanto portador e comunicador do Novo Ser.

Tillich, aprofunda mais sua mensagem cristã, quando enfatiza que a verdade cristã não é a verdade doutrinária, mas a verdade que é o próprio Cristo enquanto portador e comunicador do Novo Ser. Isso é esclarecido de modo brilhante no sermão intitulado "O que é a verdade?". Partindo da pergunta de Pilatos a Jesus ("o que é a verdade?"). De acordo com (Arrington, e Stronstad,1999, p. 597): ${ }^{16}$ na narrativa joanina, os líderes judeus, sem entrarem no palácio, levam Jesus a Pilatos porque não querem se contaminar antes da Páscoa adentrando num edifício gentio Pilatos sai e lhes pergunta quais são as acusações. O diálogo entre ele e os líderes judeus mostra só ambiguidades concernentes as acusações. Pilatos diz a eles que o julguem de acordo com a própria lei deles. Eles têm certa autoridade sob a lei romana, e a lei rabínica regulava a pena de morte. Pouco tempo depois, este mesmo grupo de judeus

16 ARRINGTON, French L. STRONSTAD, Roger. Full Life Commentary to the New Testament. Zondedervan Publishing House Grand Rapids, Michigan, USA, 1999. 
apedreja Estevão (At 7). Podemos tecer vários comentários. João sugere que o julgamento de Jesus é ilegal. Casos capitais têm de ir perante o Sinédrio, em Jerusalém. Em João, eles não se reúnem.

Em Atos 7, o Sinédrio se reuniu e liquidou Estêvão. O caso é que os líderes judeus querem que Jesus seja crucificado e desejam que os romanos o façam, passando-lhes a responsabilidade, pois sabiam que os romanos exerciam a pena de morte por crucificação. Tanto eles quanto Pilatos passam Jesus de um lado para o outro, e não assumem a responsabilidade por sua morte. Pilatos não pode suportar mais nenhuma desordem dos judeus. Os líderes judeus colocam-no numa situação difícil. João oferece "a verdadeira" explicação no versículo 32. Os fatos estão acontecendo de acordo com o plano de Deus; este tipo de morte cumpre as próprias palavras de Jesus. Note os vários lugares onde Jesus falou a esse respeito: 1) João 3.14: "Assim importa que o Filho do Homem seja levantado"; 2) João 8.28: "Quando levantardes o Filho do Homem"; 3) João 12.32,33: "E eu, quando for levantado da terra, todos atrairei a mim. E dizia isso significando de que morte havia de morrer".

Tillich não se detêm em conceitos dogmáticos religiosos, ele busca no evangelho joanino alguns ditos de Jesus sobre a verdade, sempre apontando para Ele mesmo: "Eu sou o caminho, a verdade e a vida... a verdade vos libertará" (João 14.6 e 8.32). (Calvani, 2004, p. 153) nos diz, que Tillich vai nos dizer assim, em um trecho do seu sermão:

Jesus não é a verdade porque seu ensino seja verdadeiro. Mas seu ensino é verdadeiro porque expressa a verdade que é Ele mesmo. Ele é maior que suas palavras. Ele é maior que qualquer palavra sobre Ele. A verdade que nos faz livres não é o ensino de Jesus nem o ensino sobre Jesus. Aqueles que são chamados a ensinar a "verdade de Jesus" acabam por escravizar as pessoas à servidão de uma nova lei. São aqueles que aceitam Jesus como pregador infalível ou doador de uma nova lei. Os ensinos de Jesus não devem ser usados como uma coleção de prescrições infalíveis para a vida. Eles apontam a verdade, mas não são a verdade. Também não são as doutrinas sobre 
Ele que nos libertam. E eu lhes digo isso na condição de alguém que tem dedicado a vida e o trabalho em prol de uma verdadeira expressão da verdade que é Cristo... tudo o que aprendemos de nossos mestres e do ensino da Igreja em todas as gerações, não é a verdade que nos liberta. A Igreja muito cedo esqueceu a palavra do evangelho de que Ele é a verdade; e passou a confundir suas doutrinas sobre Ele com a verdade que Ele é.

Paul Tillich, nos dá outras razões porque a mensagem cristã tem se tornado irrelevante hoje em dia. Para ele, o conteúdo moralista e ético, tem deformado a mensagem cristã. As lideranças estão preocupas somente em manter o povo em uma bolha da religiosidade. Enquanto a real tarefa social da igreja, é deixada de lado. As classes mais oprimidas, são esquecidas. Para ele, esses líderes só estão preocupados com a preservação institucional. Apesar disso, Tillich acredita ser possível um resgate do verdadeiro evangelho e da mensagem cristã.

\section{Considerações finais}

Não há dúvida, que Tillich é ainda considerado um dos melhores teólogos e pregadores de todos os tempos. Nele, estão presentes o pastor, acadêmico e o teólogo. Ele se destaca pelas mensagens, repletas de uma profunda espiritualidade. E toda sua trajetória de vida, ele esteve comprometido com a igreja, sociedade e religião. Tillich é chamado por muitos estudiosos, de teólogo da fronteira, por sua capacidade de transitar em várias áreas do estudo teológico e filosófico. Ele não foi só um simples pastor de igreja local, serviu como capelão na I Guerra Mundial, o que lhe trouxe inúmeras experiências. Ele presenciou de perto, os dramas da existência humana. Teve capacidade de atravessar os limites a linguagem poética, da existencialidade e do compromisso político, chegando a elaborar uma análise criteriosa da filosofia religiosa da sua época. A dimensão cultural de seus escritos, até hoje, auxilia estudantes e pesquisadores. A imaginação filosófica do seu pensamento, possibilitam vários olhares, são elementos que fundamentam uma profunda reflexão teológica. Foi um grande humanista, pois, propôs uma ampla preocupação socialista. 
A natureza de sua linguagem teológica e filosófica, nos ajudam na compreensão dos significados e sentidos imprescindíveis dos símbolos na mensagem cristã. Sem deixar de refletir as marcas do homem de seu tempo, Tillich assumiu uma postura proponente, fazendo da mensagem e da pregação cristã uma arte repleta de simbolismos de uma verdadeira espiritualidade. A riqueza literária de suas obras, estão presentes não só em grupos de estudos em universidades, mas também no aspecto religioso, é preciso se deixar influenciar por esse importante pensador. Tillich fez da igreja, seu lar e da universidade um centro de estudos elaborados que perpassam o tempo. Para ele, a cultura é a produção humana em toda sua riqueza e profundidade. Tillich rejeitou a leitura natural da teologia, por não a considerar em consonância com a tradição bíblica e da mensagem dos reformadores protestantes. Para ele, a teologia deve refletir não só sobre a presença de Deus, mas também sua alteridade, já que a alteridade não é sinônimo de ausência. É a partir de dessa perspectiva, que Tillich fundamenta seu pensamento: a correlação da mensagem com a situação existencial. O aspecto simbólico da linguagem religiosa que evita a apropriação, dogmatismo e idolatria e o princípio protestante, que define a justiça como incondicionalidade, mas expressa uma busca humana. A tarefa da teologia para Tillich, deve refletir essas questões primordiais da existência humana. As desse grande teólogo e filosofo, é um grande legado para todos nós.

\section{Referências}

ARRINGTON, French L. STRONSTAD, Roger. Full Life Commentary to the New Testament. Zondedervan Publishing House Grand Rapids, Michigan, USA, 1999.

BOTElHO, José Francisco. A história da Primeira Guerra Mundial. Super interessante. Disponível em: https://super.abril.com.br/especiais/a-historia-da-primeira-guerra-mundial/. Consulta realizada em: 14 de fevereiro de 2021.

CAMPOS, Flavio de; MIRANDA, Renan Garcia. A escrita da história: volume único. 1 ${ }^{\text {a }}$. Ed. São Paulo, 2005.

CALVANI, Carlos Eduardo B. Espiritualidade e Pregação. Revista Eletrônica Correlatio n. 6 - novembro de 2004.

GRENZ, Stanley J.; OLSON, Roger E. A teologia do século 20 - Deus e o mundo numa era de transição. São Paulo: Cultura Cristã, 2003. 
HORDERN, William E. Teologia contemporânea. São Paulo: Hagnos, 2003. PARRELLA, Frederick J. Vida e Espiritualidade no pensamento de Paul Tillich.

EDUCAÇÃO, Mundo. Idealismo. Disponível em: https://mundoeducacao.uol. com.br/filosofia/idealismo.htm\#: :text=Os\%20fil $\%$ C3\%B3sofos $\% 20 \mathrm{do} \% 20$ idealismo\%20alem\%C3\%A3o,Friedrich\%20Wilhelm\%20Joseph\%20Schelling. Consulta realizada em: 23 de fevereiro de 2021.

Revista Eletrônica Correlatio n. 6 - novembro de 2004. Disponível em: https://www.metodista.br/revistas/revistas-ims/index.php/COR/article/viewFile/1764/1750. Consulta realizada em: 28 de janeiro de 2021.

TILLCH, Paul Johannes. No Limite. Organizador - São Paulo - Fonte Editorial, 2016.

TILLICH, Paul Johannes. Teologia Sistemática. 5.ed. São Leopoldo: Ed. Sinodal, 2005. p.63.

TILLICH, Paul Johannes. Textos Selecionados. São Paulo. Fonte Editorial, 2020.

TILLICH, Paul Johannes. Teologia da Cultura. São Paulo. Fonte Editorial, 2009.

WIERSBE, Warren W. Comentário Bíblico Novo Testamento - A Bíblia explicada de maneira clara e concisa. $1^{a}$ edição, Rio de Janeiro: 2009.

ZUBEN, Reginaldo von. Teologia e Igreja. Fatipi - Faculdade de Teologia de São Paulo - 8 de novembro de 2019. Disponível em: https://www.fatipi. edu.br/post/teologia-e-igreja. Consulta realizada em: 30 de janeiro de 2021. 